\title{
EVALUATION OF THE ADEQUACY OF THE WIND SPEED EXTRAPOLATION LAWS FOR TWO DIFFERENT ROUGHNESS METEOROLOGICAL SITES
}

\author{
${ }^{1}$ Dalila Khalfa, ${ }^{1}$ Abdelouaheb Benretem, ${ }^{2}$ Lazher Herous and ${ }^{1}$ Issam Meghlaoui \\ ${ }^{1}$ Electromecanical Engineering Laboratory, Badji Mokhtar-Annaba University, B.O. Box 12, 23000 Annaba, Algeria \\ ${ }^{2}$ Electrical Engineering Laboratory Guelma (LGEG), 8 May 1945 University, B.O. Box 401, 24000 Guelma, Algeria
}

Received 2013-12-13; Revised 2013-12-24; Accepted 2014-02-01

\begin{abstract}
Increasing knowledge on wind shear models to strengthen their reliability appears as a crucial issue, markedly for energy investors to accurately predict the average wind speed at different turbine hub heights and thus the expected wind energy output. This is particularly helpful during the feasibility study to abate the costs of a wind power project. The extrapolation laws were found to provide the finest representation of the wind speed according to heights, thus avoiding installation of tall towers, or even more expensive devices such as LIDAR or SODAR. The proposed models are based on theories that determine the vertical wind profile from implicit relationships. However, these empirical extrapolation formulas have been developed for specific meteorological conditions and appropriate sites for wind turbines; reason that several studies have been made by various authors to determine the best suited formula to their own conditions. This study is aimed at proceeding the research issue addressed within a previous study, where some extrapolation models were tested and compared by extrapolating the energy resources at different heights. However, comparable results are returned by the power law and the log law which indeed proved to be preferable. In this context, this study deals the assessment of several wind speed extrapolation laws (six laws), by comparing the analytical results obtained with real data for two different meteorological Sites, different roughness, different altitudes and different measurement periods. The first site studied is an extremely rough site with daily measurements of March 2007, wind speed measurements are available at four different heights of Gantour/Gao site, obtained by the water, energy and environment company Senegal. The second site studied is a feeble rough site with monthly measurements for 2005, wind speed measurements are available at three different heights of Kuujjuarapik Site obtained by Hydro-Quebec Energy Helimax Canada. The study aims to determine the effectiveness and concordance between the extrapolation laws and the real measured data. The results show that the adjusted law is efficiently adequate for an extremely rough site and the modified laws with two other laws are efficiently adequate for a feeble rough site. The experimental results and numerical calculations exploited for the evaluation of the Weibull parameters fall the shape factors $\mathrm{k}$ greater than 9 . The increase in altitude often causes an increase in the Weibull parameters values, however, our results show that the shape factor $\mathrm{k}$ can take lower values to those established in the reference altitude.
\end{abstract}

Keywords:Wind Speed, Extrapolation Laws, Weibull Parameters, Meteorological Sites, Measure of Dispersion, Roughness

Corresponding Author: Dalila Khalfa, Electromecanical Engineering Laboratory, Badji Mokhtar-Annaba University, B.O. Box 12, 23000 Annaba, Algeria 


\section{INTRODUCTION}

Winds are large-scale movements of air masses in the atmosphere. These movements of air are created on a global scale primarily by differential solar heating of the Earth's atmosphere. Therefore, wind power can be thought of as an indirect form of solar energy. The differential heating of the sea and land also causes changes to the general flow. The nature of the terrain, ranging from mountains and valleys to more local obstacles such as buildings and trees, also has an important effect. The result is that the wind varies continuously, with height, roughness and over hills.

In addition, the enormous amount information provided by meteorological stations requires an effective tool data Processing for their use in planning proven energy investments and more accurate wind energy.

Currently this energy type has a share of more and more important in the world, however, several studies and mathematical formulas have been developed whose aim to pull the maximum possible kinetic energy.

Several models of the wind speed according to the soil altitude was established, the validity models depends very largely on climatic zones (geographic location, shear coefficient, roughness length, period and direction.

If the wind speed measurements at heights relevant to wind energy exploitation lacks, it is often necessary to extrapolate observed wind speeds from the available heights to turbine hub height, which causes some critical errors between estimated and actual energy output, if the roughness, cannot be determined correctly. The difference between the predicted and observed wind energy production might be up to $40 \%$, due to turbulence effects, time interval of wind data measurement and the extrapolation of the data from reference height to hub heights.

In the literature, the roughness $z_{0}$ is generally approximated between 0.03 and 0.1 (shear coefficient between 0.14 and 0.2 ). However, in real situations, a wind shear coefficient (roughness) is not constant and depends on numerous factors, including atmospheric conditions, temperature, pressure and humidity, time of day, seasons of the year, the mean wind speed, direction and nature of terrain. Table 1 demonstrates the various roughness's for different types of topography. $\underline{\text { Table 1. Roughness class } \mathrm{z}_{0} \text { and terrain surface characteristics }}$

\begin{tabular}{lll}
\hline Terrain type & $\mathrm{z}_{0}$ & $\mathrm{n}$ \\
\hline Water areas (lakes, fjords, open sea) & 0.0002 & 0.10 \\
Farmland with very few building and trees & 0.0300 & 0.15 \\
Farmland with closed appearance & 0.1000 & 0.20 \\
City area with tall buildings & 0.4000 & 0.25 \\
Small town with some trees & 0.8000 & 0.30 \\
\hline
\end{tabular}

The accuracy of wind speed profiles predicted using measurements at only one or a few heights near the surface has been of interest to researchers for quite awhile. There have been a number of prior studies that examined how power law exponents varied as a function of location, time and other factors.

Mikhail (1985) examined the use of four different methods of predicting the wind profile at several tall towers in the American Midwest using anemometer data from a single level. He observed that the use of a modified power law expression was more accurate than application of the $1 / 7$ power law or logarithmic laws.

Schwartz and Elliott (2006) observed that annual average values of $\mathrm{n}$ were 0.15 to 0.25 , well in excess of $1 / 7$, at thirteen tall towers in the American plains states. Significant diurnal variations were observed, as well as some seasonal fluctuations.

Ray et al. (2006) found significant variation with wind direction at Boulder, a site in complex terrain. Other recent studies include those by (Motta et al., 2005; Perez et al., 2005; Rogers et al., 2005).

While several researchers have investigated how power law exponents or logarithmic fits vary in wind speed profiles, there has been less investigation relating these findings to the practical question of how much uncertainty is introduced when these methods are applied to predicting turbine hub-height wind speeds from lower height anemometer data.

In general the power law and the log law exhibit a good accuracy for roughness and shear coefficient in the usual range of measurement. In this study, we chose two completely different sites and outside the usual range of roughness and shear coefficient, by reason to see and whether these laws will give the same certainty that show in the usual study conditions.

\section{DISCRIPTION OF METEOROLOGICAL SITES}

The goal attempts to evaluate and compare six laws extrapolation of the wind speed with real data, 
considering two completely different meteorological sites for assess the adequacy and adjustment of results obtained using a extrapolation calculation laws with the real data.

the first site studied is a very rough site with roughness $z_{0}=0.4 \mathrm{~m}$ (Fig. 1), the measuring sensors are installed at four levels $\left(\mathrm{z}_{1}=17 \mathrm{~m}, \mathrm{z}_{2}=29 \mathrm{~m}, \mathrm{z}_{3}=\right.$ $\left.39 \mathrm{~m}, \mathrm{z}_{4}=40 \mathrm{~m}\right)$, the treatment was based on 31 full days, representing 4464 intervals of $10 \mathrm{~min}, 100 \%$ of the intervals are valid, the average form all daily measures of March 2007, the measure of dispersion E does not exceed $3 \mathrm{~m} \mathrm{sec}^{-1}$ with $v_{\min }=5 \mathrm{~m} \mathrm{sec}^{-1}$ and $v_{\max }=8 \mathrm{~m} \mathrm{sec}^{-1}$ for all altitudes, (Fig. 2).

The second site studied is a rough site with roughness $z_{2}=0.024 \mathrm{~m}$ (Fig. 3), the mat of this site is equipped with instruments at three levels $\left(\mathrm{z}_{1}=30 \mathrm{~m}\right.$, $\mathrm{z}_{2}=40 \mathrm{~m}, \mathrm{z}_{3}=50 \mathrm{~m}$ ), the monthly variation of wind speed during the observation period forms the monthly measures of 2005 , the measure of dispersion E does not exceed $3 \mathrm{~m} \mathrm{sec}^{-1}$ with $v_{\min }=6 \mathrm{~m} \mathrm{sec}^{-1}$ and $v_{\max }=9 \mathrm{~m} \mathrm{sec}^{-1}$ for all altitudes, (Fig. 4).

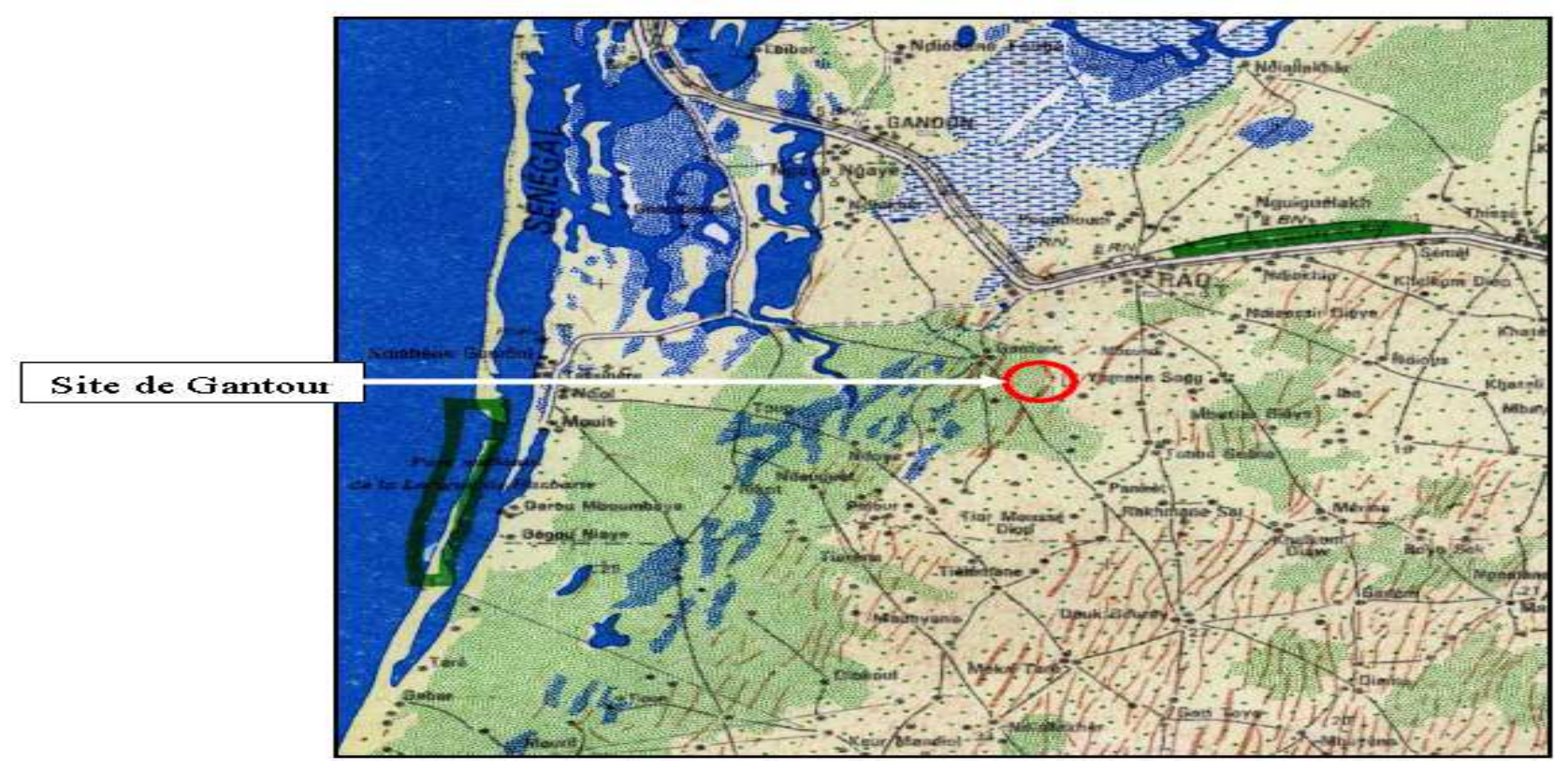

Fig. 1. Gantour site location

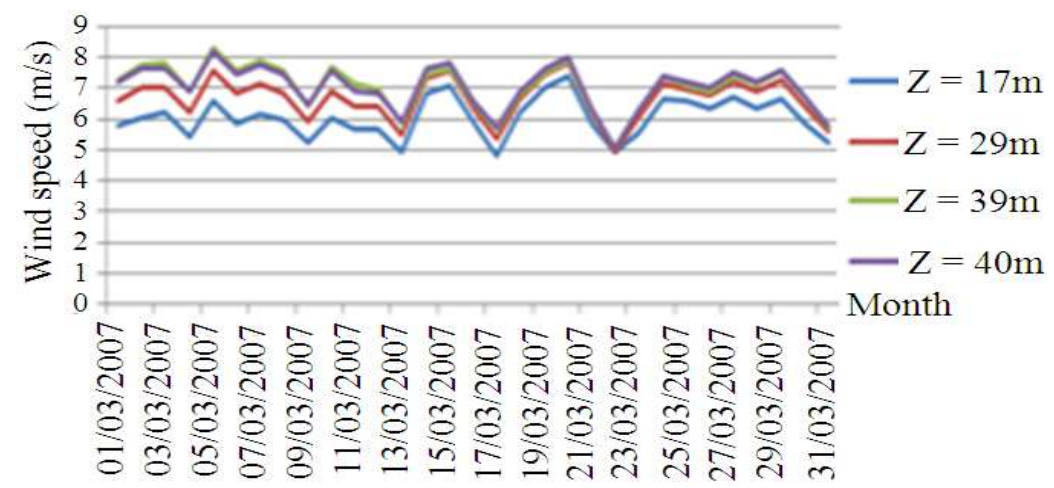

Fig. 2. Real data of gantour site (all altitudes) 
Dalila Khalfa et al. / American Journal of Applied Sciences 11 (4): 570-583, 2014

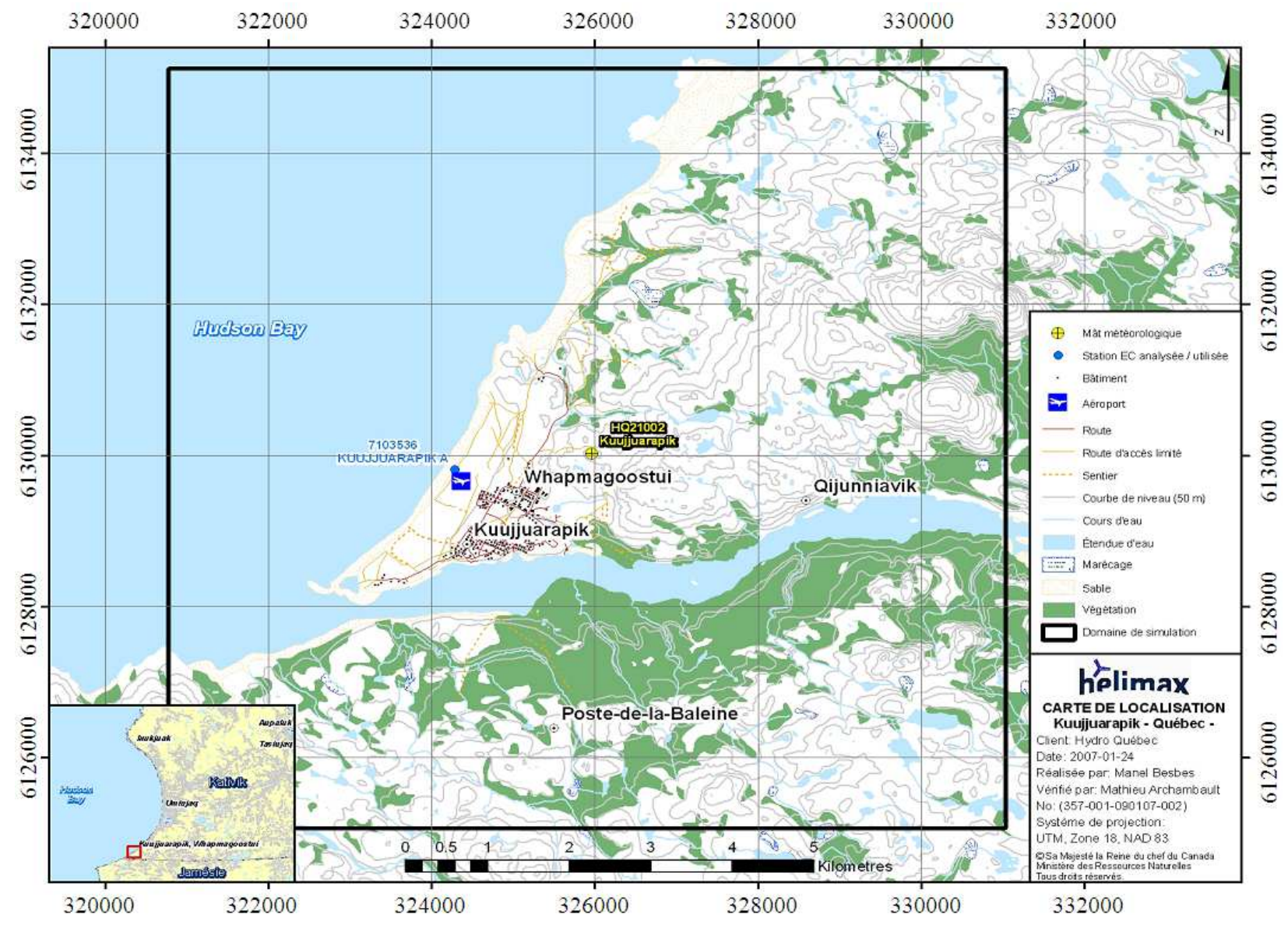

Fig. 3. Kuujjuarapik site location

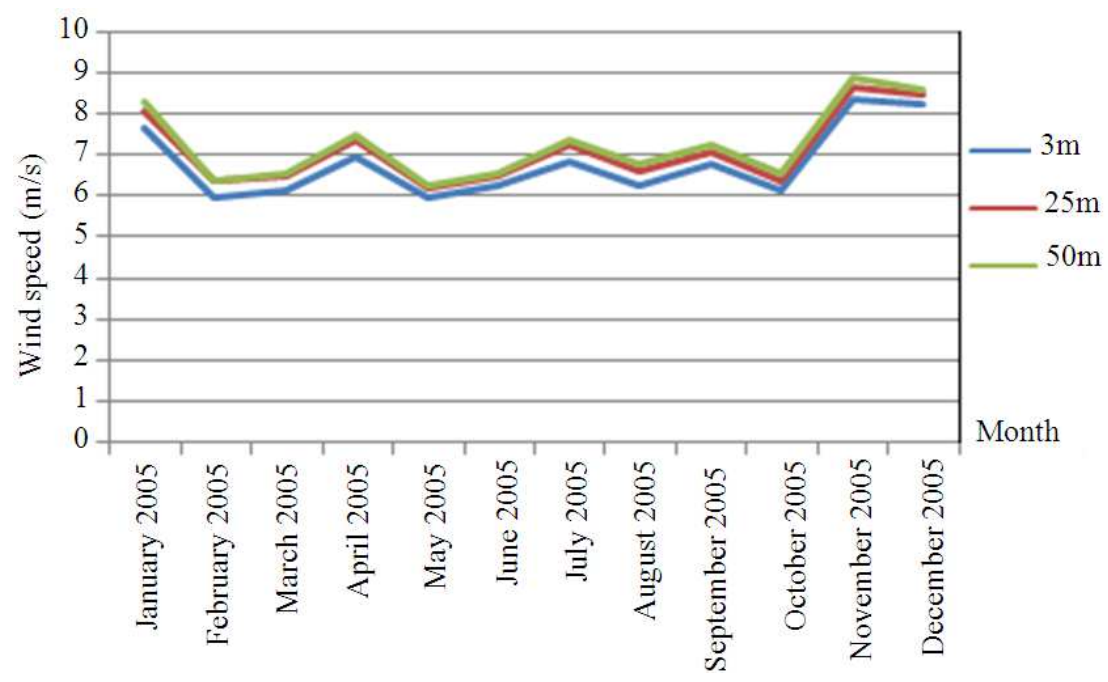

Fig. 4. Real data of kuujjuarapik site (all altitudes) 


\section{WIND SPEED EXTRAPOLATION LAWS}

Calculating the wind profile to estimate the increase in wind speed with height, among the multitude of extrapolation formulas available, we a priori selected six laws (Justus and Mikhail, 1976; Peterson and Hennessey, 1978).

\subsection{The Log Law}

A logarithmic law can represent the variation of wind speed with height for neutrally stable conditions as fellow Equation (1) (Tennekes, 1973; Troen and Peterse, 1998):

$$
v_{1}=v_{2}\left(\frac{z_{2} / z_{0}}{z_{1} / z_{0}}\right)
$$

\subsection{The Power Law}

For estimation of the mean wind speed distribution with height a simple power law can be used to provide a reasonable fit to the data and is given by Equation ( 2 and 3) (Mikhail and Justus, 1981):

$$
\begin{aligned}
& v_{2}=v_{1}\left(z_{2} / z_{1}\right)^{n} \\
& \mathrm{n}=\mathrm{a}+\mathrm{b} \times \operatorname{In}\left(\mathrm{v}_{1}\right)
\end{aligned}
$$

$\mathrm{a}$ and $\mathrm{b}$ are given by the following formulas (Mikhail, 1985) Equation (4 and 5):

$$
\begin{aligned}
& a=\frac{0.37}{\left[1-0.0881 \times \operatorname{In}\left(z_{1} / 10\right)\right]} \\
& b=\frac{-0.0881}{\left[1-0.0881 \times \operatorname{In}\left(z_{1} / 10\right)\right]}
\end{aligned}
$$

\subsection{The One Seven Power Law}

The one seven power law is the limit of similarity model where the expression (Justus et al., 1976) Equation (6):

$$
v_{1}=v_{2}\left(z_{2} / z_{1}\right)^{1 / 7}
$$

\subsection{Modified Power Law}

For uncharged stability conditions, the exponent of the power law is put in the form Equation (7) (Hsu et al., 1994; Poje and Cividini, 1988):

$$
n=\frac{1}{\operatorname{In}\left(\frac{z_{g}}{z_{0}}\right)}-\left[\frac{0.0881}{1-0.0881 \times \operatorname{In}\left(v_{1} / z_{0}\right)}\right] \times \operatorname{In}\left(\frac{v_{1}}{v n}\right)
$$

$v_{\mathrm{n}}=6 \mathrm{~m} \mathrm{sec}^{-1}$ for uncharged stability conditions.

\subsection{Modified Power Law}

The researchers adjust experimentally the previous model and offer the following expression Equation (8) (Manwell et al., 2010):

$$
n=\frac{1}{\operatorname{In}\left(\frac{z_{g}}{z_{0}}\right)}-\left[\frac{0.0881 \times\left(1-v_{1}\right)}{1-0.0881 \times \operatorname{In}\left(v_{1} / z_{0}\right)}\right]
$$

\subsection{Variable Coefficient Law}

The empirical formula whose exponent is variable coefficient, depending on the roughness (Nfaoui et al., 1998), namely Equation (9):

$$
\begin{array}{ll}
n=\frac{\chi-0.0881 \times \operatorname{In}\left(v_{1}\right)}{\left[1-0.0881 \times \operatorname{In}\left(z_{1} / 10\right)\right]} \\
z_{0}=0 \div 0.005 \mathrm{~m} \quad \chi=0.25 \\
z_{0}=0.005 \div 0.05 \mathrm{~m} \quad \chi=0.31 \\
z_{0}=0.05 \div 0.5 \mathrm{~m} \quad \chi=0.37 \\
z_{0}=0.5 \div 4 \mathrm{~m} & \chi=0.48
\end{array}
$$

\section{WEIBULL PARAMETERS ESTIMATION}

The wind speed is an important random variable which affects the most accurate results on the energy potential of the site. The wind speed in a given period may be represented by a probability density function. In recent years the Weibull distribution has been one of the most widely used and recommended tool to determine the potential of wind energy. Moreover, it is used as a benchmark to estimate the wind energy commercially viable (Rocha et al., 2012). The Weibull distribution can be described as a probability density function $f(v)$, determined by the following Equation (10) (Justus et al., 1978):

$$
F(v)=\kappa /{ }_{C}\left(v /{ }_{C}\right)^{k-1} \exp \left(-\left(v /{ }_{C}\right)^{k}\right)
$$

The empirical method is one of the most efficient methods for the estimate of Weibull parameters. The 
shape parameter $\mathrm{k}$ and scale parameter $\mathrm{c}$ of Weibull distribution can give by the equations shown below (Elkinton et al., 2006) Equation (11 and 12):

$$
\begin{aligned}
& \mathrm{K}=\left(\frac{\sigma}{\bar{v}}\right)^{-1,096} \\
& c=\frac{v}{\Gamma(1+1 / k)}
\end{aligned}
$$

\section{RESULTS}

\subsection{Daily Data}

The statistical calculation and Weibull parameters evaluation using the empirical method are summarized in Table 2.

Figure 5 shows the allure of the probability density for the four altitudes depending on the wind speed.

Figure 6 to 8 present the real measured points and the extrapolated points (using the six laws of wind speed extrapolation) of the reference height $\left(z_{1}=17 \mathrm{~m}\right.$ to $\left.\mathrm{z}_{2}=29 \mathrm{~m}\right),\left(\mathrm{z}_{1}=17 \mathrm{~m}\right.$ to $\left.\mathrm{z}_{2}=39 \mathrm{~m}\right)$ and $\left(\mathrm{z}_{1}=17 \mathrm{~m}\right.$ to $\left.\mathrm{z}_{2}=40 \mathrm{~m}\right)$.

Figures 9 to 11 show the density distribution of real and extrapolated daily data around their average.

Table 4 to 6 collect all daily results (real and extrapolated) analyzed and compared with the real data.

\subsection{Monthly Data}

The statistical calculation and Weibull parameters evaluation using the empirical method are summarized in Table 3.

Figure 12 shows the allure of the probability density for the four altitudes depending on the wind speed.

Figure 13 and 14 present the measured points and the calculated points (using the six laws extrapolation) of the reference height $\left(\mathrm{z}_{1}=30 \mathrm{~m}\right.$ to $\mathrm{z}_{2}=$ $40 \mathrm{~m}),\left(\mathrm{z}_{1}=30 \mathrm{~m}\right.$ to $\left.\mathrm{z}_{3}=50 \mathrm{~m}\right)$.

Figure 15 and 16 show the distribution of real and extrapolated monthly data around their average.

\begin{tabular}{|c|c|c|c|c|}
\hline \multirow[b]{2}{*}{$\begin{array}{l}\text { Daily data } \\
\text { at altitude }\end{array}$} & \multicolumn{2}{|c|}{ Statistic results } & \multicolumn{2}{|c|}{ Weibull parameters } \\
\hline & $\overline{\mathrm{v}}\left(\mathrm{msec}^{-1}\right)$ & $\delta$ & $\mathrm{k}$ & $\mathrm{c}\left(\mathrm{m} \mathrm{sec}{ }^{-1}\right)$ \\
\hline $17 \mathrm{~m}$ & 6.0658 & 0.6627 & 11.0724 & 6.3495 \\
\hline $29 \mathrm{~m}$ & 6.6468 & 0.6976 & 11.5665 & 6.9458 \\
\hline $39 \mathrm{~m}$ & 7.0506 & 0.7775 & 10.9616 & 7.3833 \\
\hline $40 \mathrm{~m}$ & 7.0506 & 0.7439 & 11.5169 & 7.3791 \\
\hline
\end{tabular}

Table 2. Statistical analysis-Gantor site at all altitudes

Table 3. Statistical analysis-Kuujjuarapik site at all altitudes

\begin{tabular}{lllll}
\hline \multirow{2}{*}{$\begin{array}{l}\text { Monthly data } \\
\text { at Altitude }\end{array}$} & $-\mathrm{v}$ - $\left(\mathrm{m} \times \mathrm{sec}^{-1}\right)$ & $\delta$ & \multicolumn{2}{l}{ Weibull parameters } \\
\hline $30 \mathrm{~m}$ & 6.8417 & 0.8607 & 9.5001 & $\mathrm{k}\left(\mathrm{m} \mathrm{sec}^{-1}\right)$ \\
$40 \mathrm{~m}$ & 7.1417 & 0.8733 & 9.7977 & 7.5134 \\
$50 \mathrm{~m}$ & 7.2750 & 0.8956 & 9.7268 & 7.6561 \\
\hline
\end{tabular}

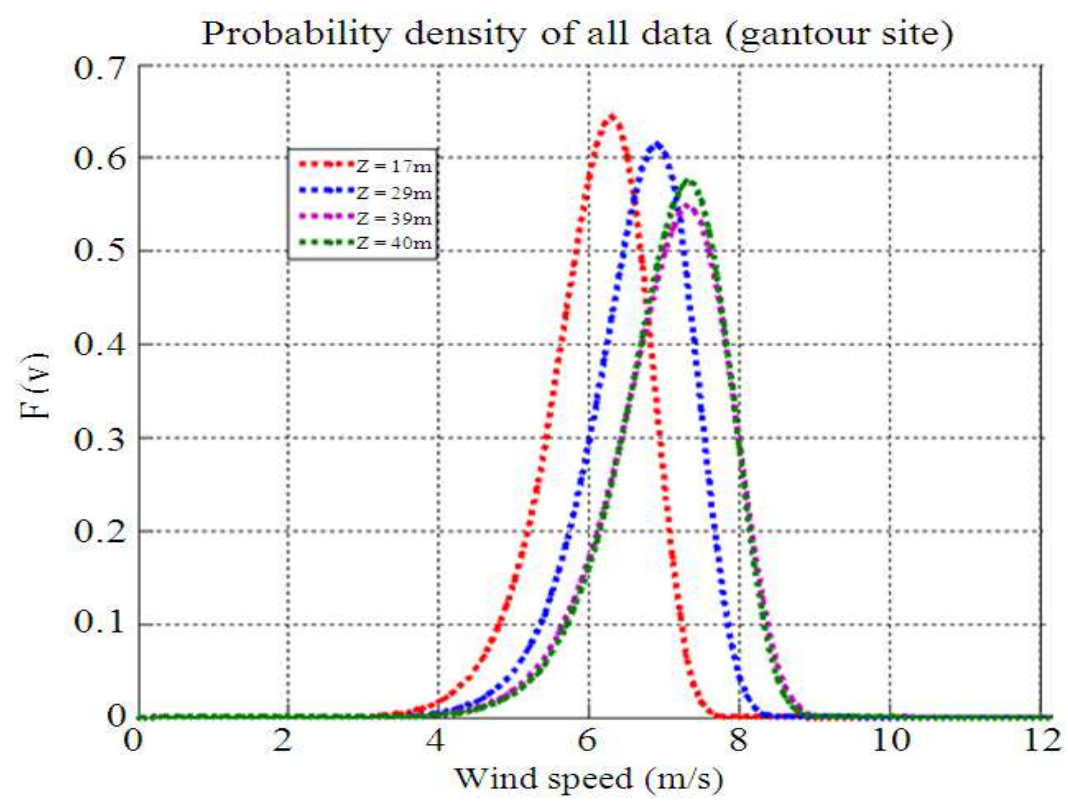

Fig. 5. Weibull distribution (Gantour site) 
Dalila Khalfa et al. / American Journal of Applied Sciences 11 (4): 570-583, 2014

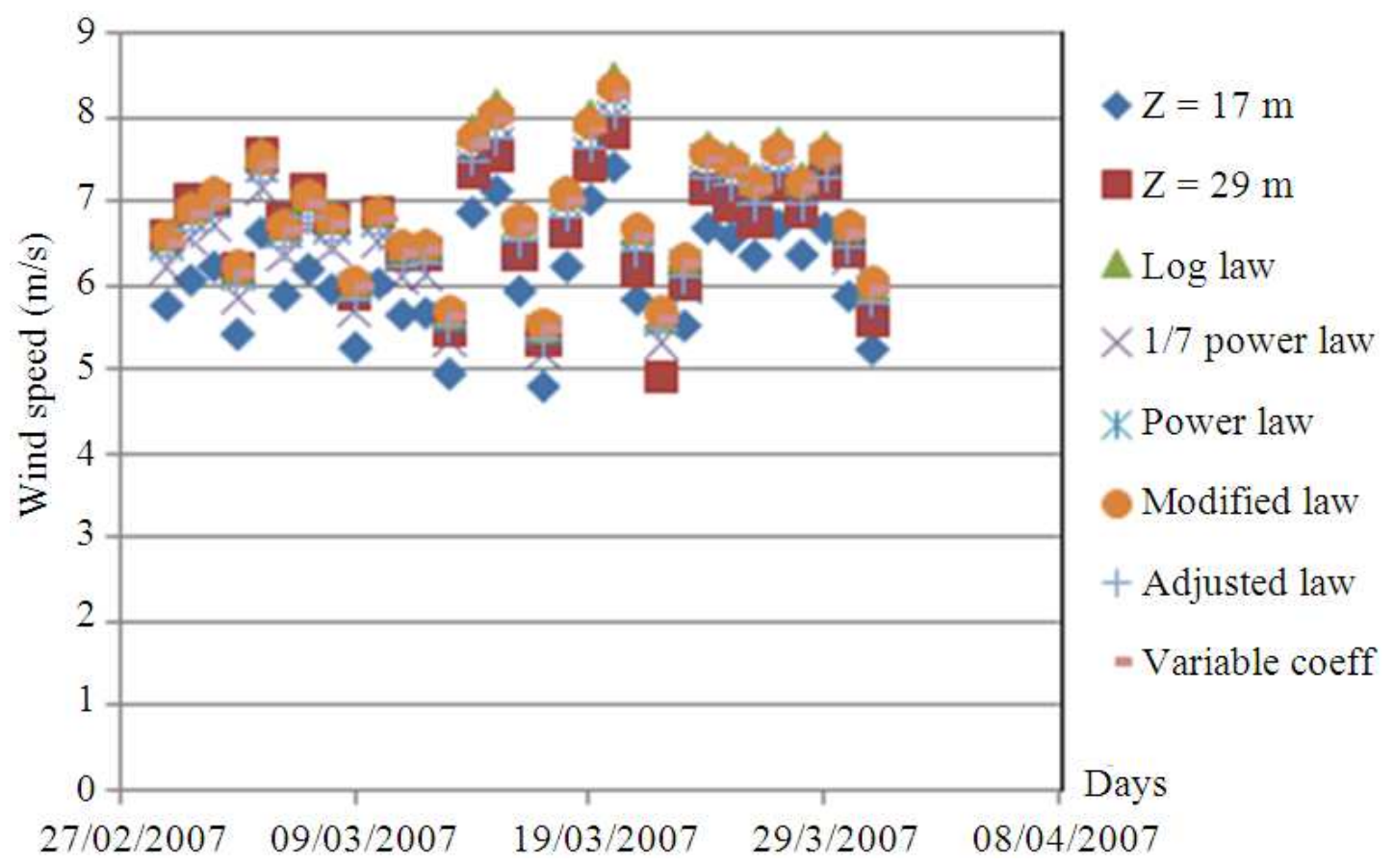

Fig. 6. Real and extrapolated data at $z=29 \mathrm{~m}$

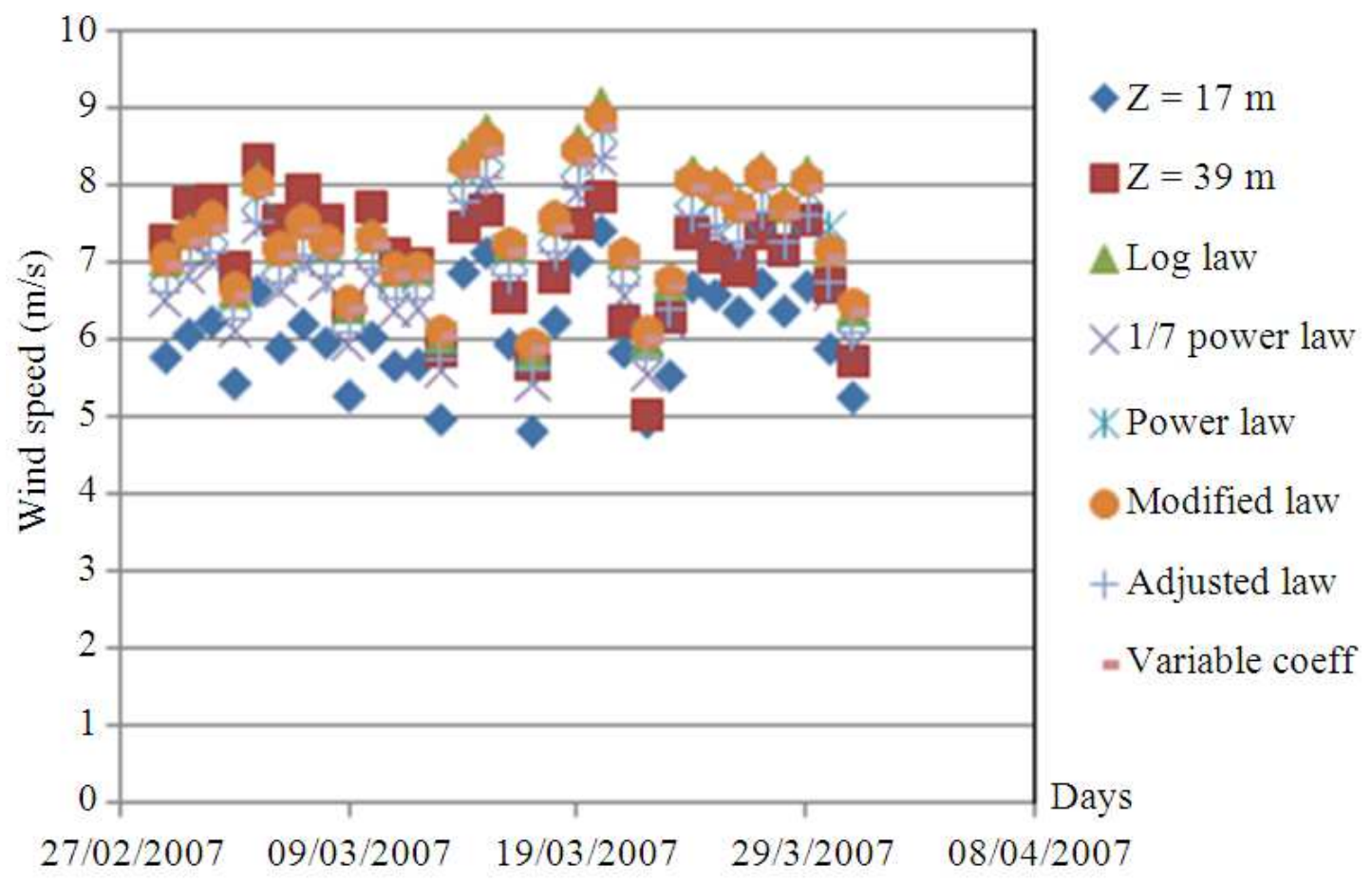

Fig. 7. Real and extrapolated data at $z=39 \mathrm{~m}$ 
Dalila Khalfa et al. / American Journal of Applied Sciences 11 (4): 570-583, 2014

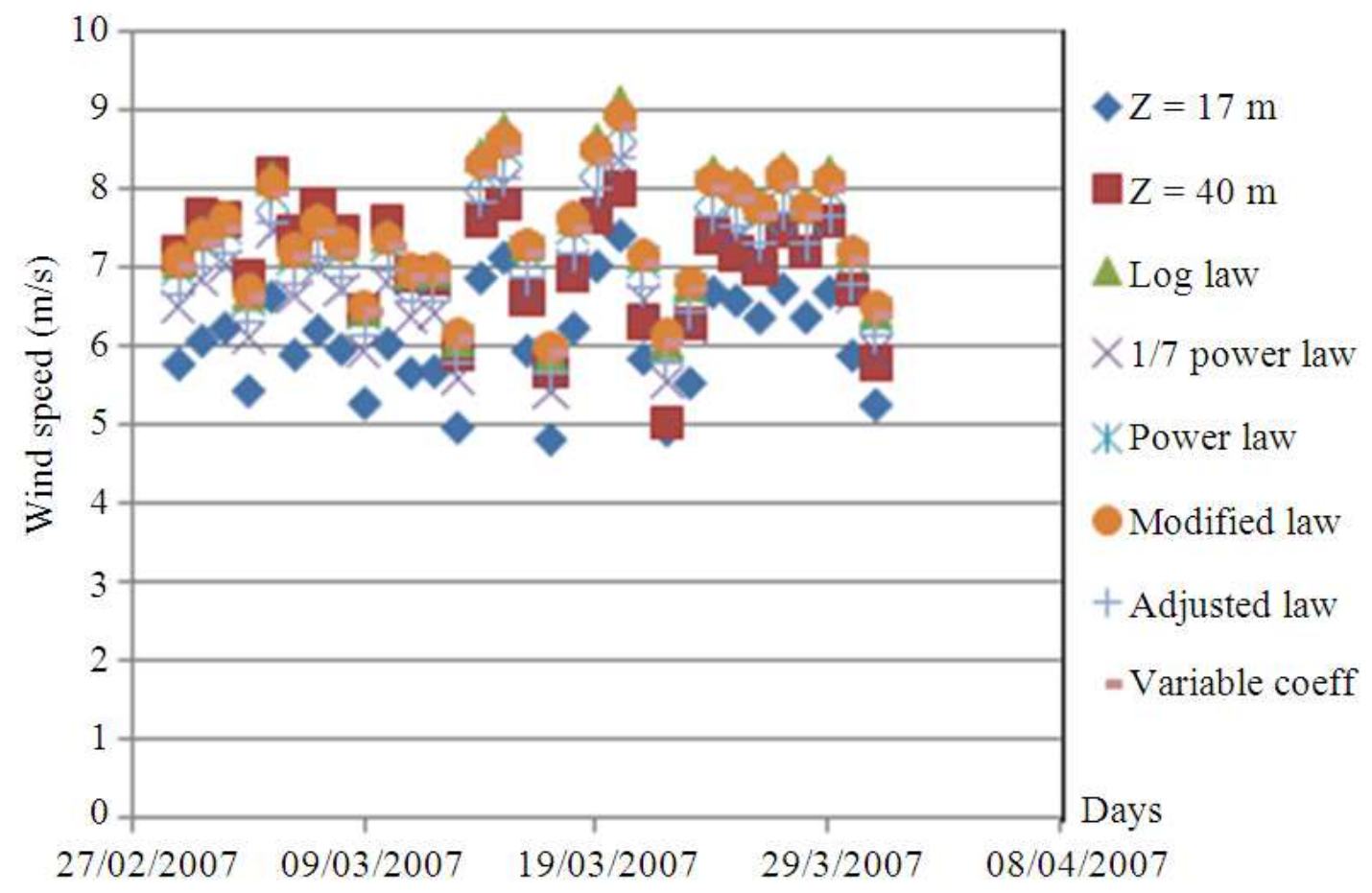

Fig. 8. Real and extrapolated data at $z=40 \mathrm{~m}$

Probability density of real and extrapolated data at $z=29 \mathrm{~m}$ (daily measurement)

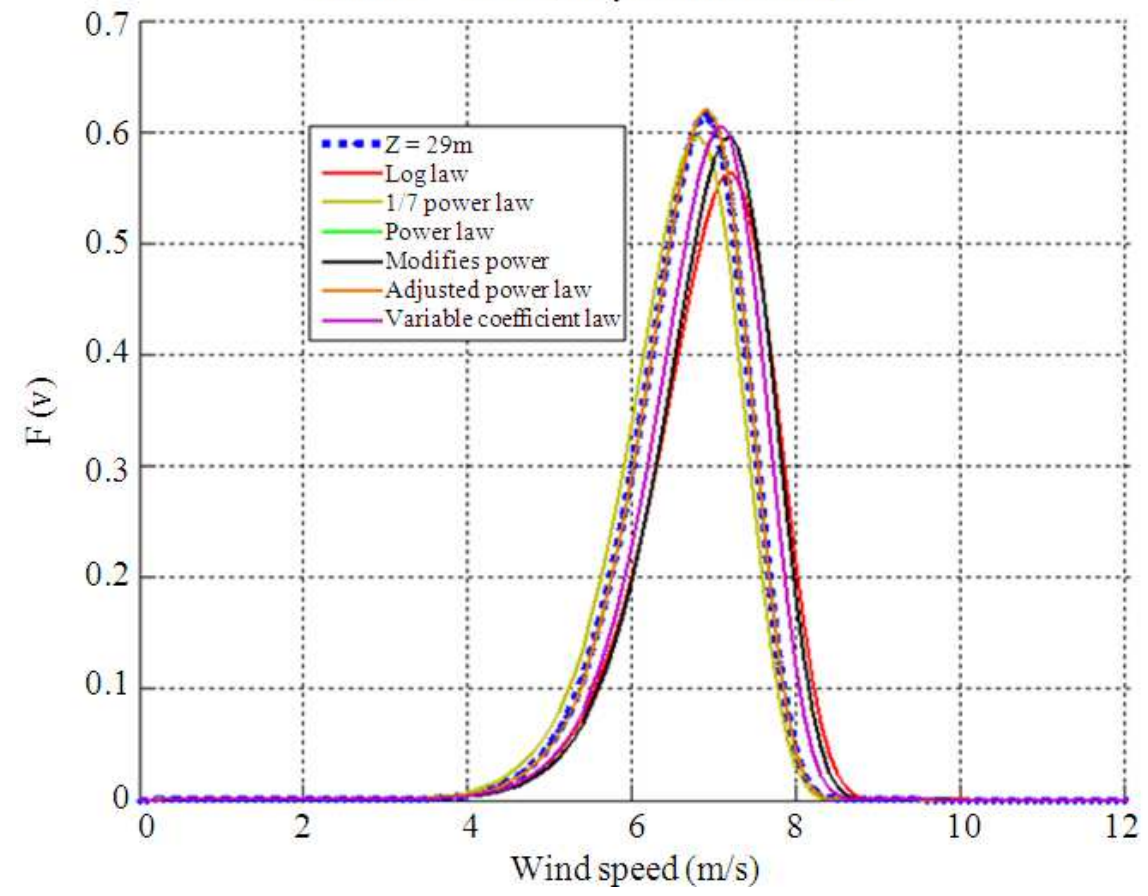

Fig. 9. Weibull distribution Real and extrapolated data $z=29 \mathrm{~m}$ 
Dalila Khalfa et al. / American Journal of Applied Sciences 11 (4): 570-583, 2014

Probability density of real and extrapolated data at $z=39 \mathrm{~m}$ (daily measurement)

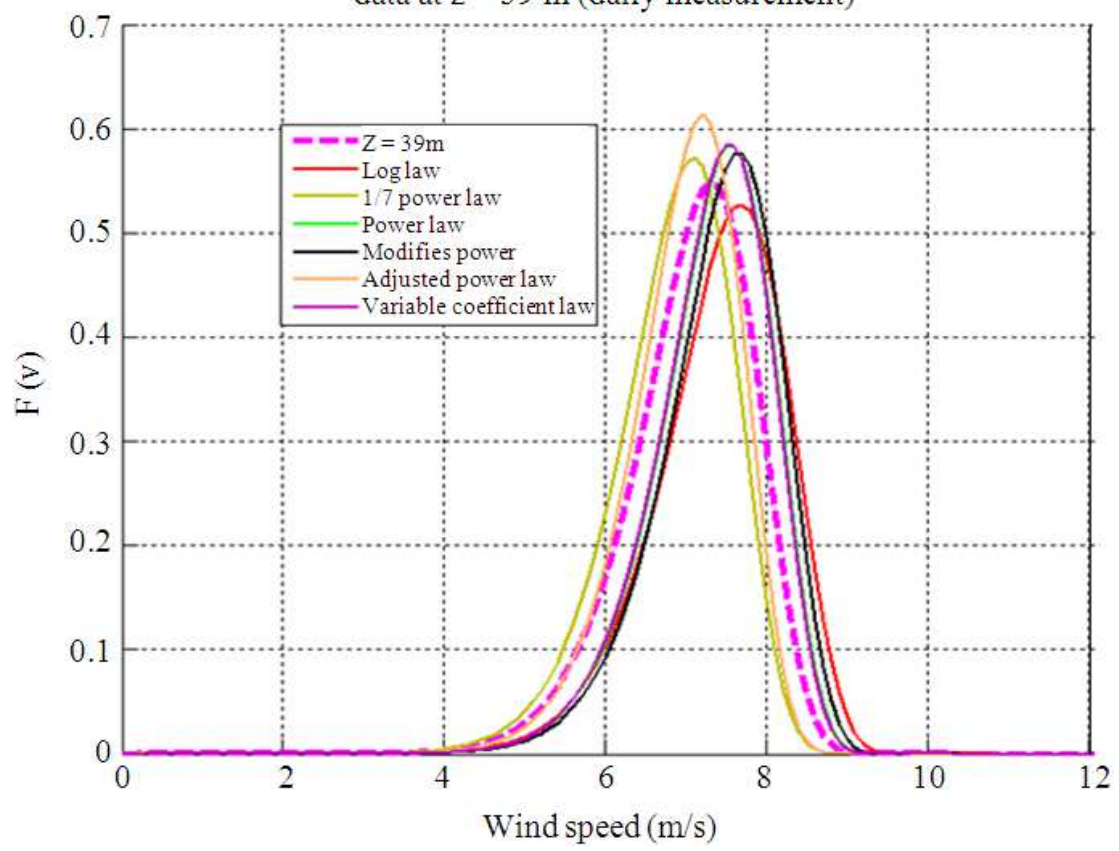

Fig. 10. Weibull distribution Real and extrapolated data $z=39 \mathrm{~m}$ (daily measurement)

Probability density of real and extrapolated data at $z=40 \mathrm{~m}$ (daily measurement)

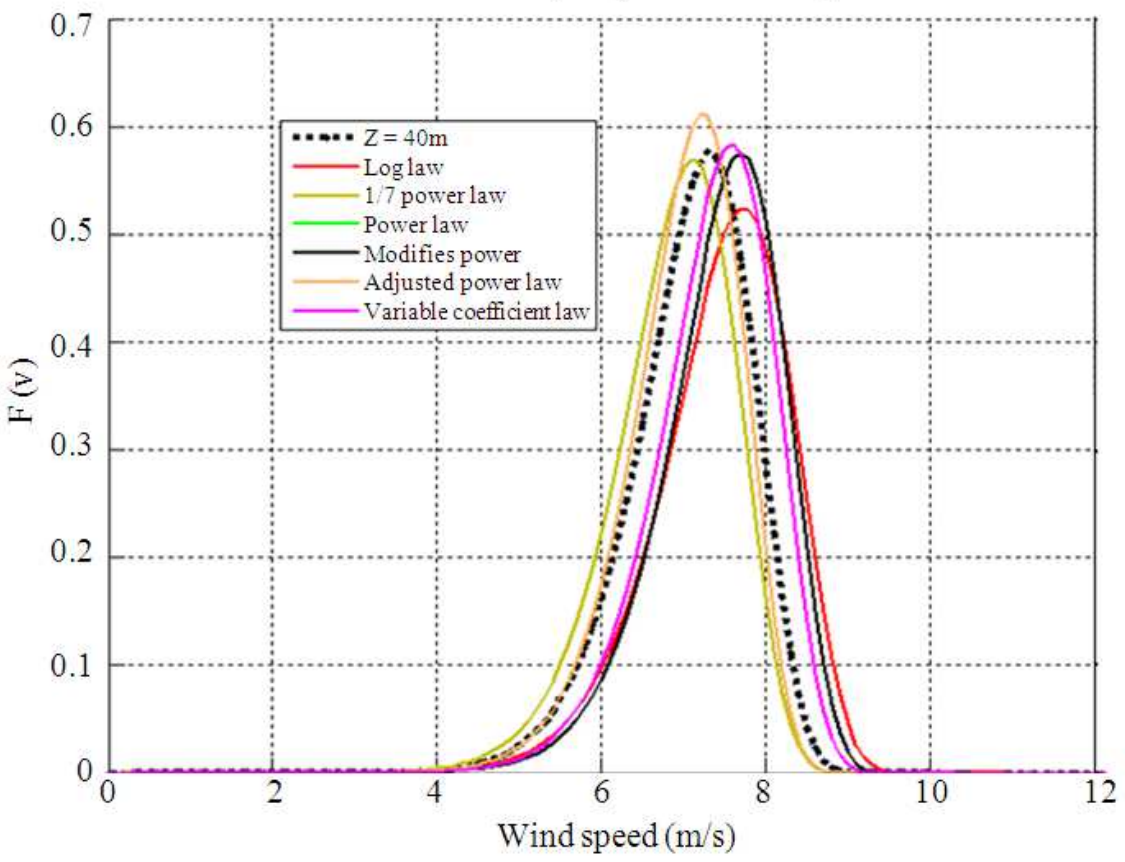

Fig. 11. Weibull distribution Real and extrapolated data $z=40 \mathrm{~m}$ (daily measurement) 
Dalila Khalfa et al. / American Journal of Applied Sciences 11 (4): 570-583, 2014

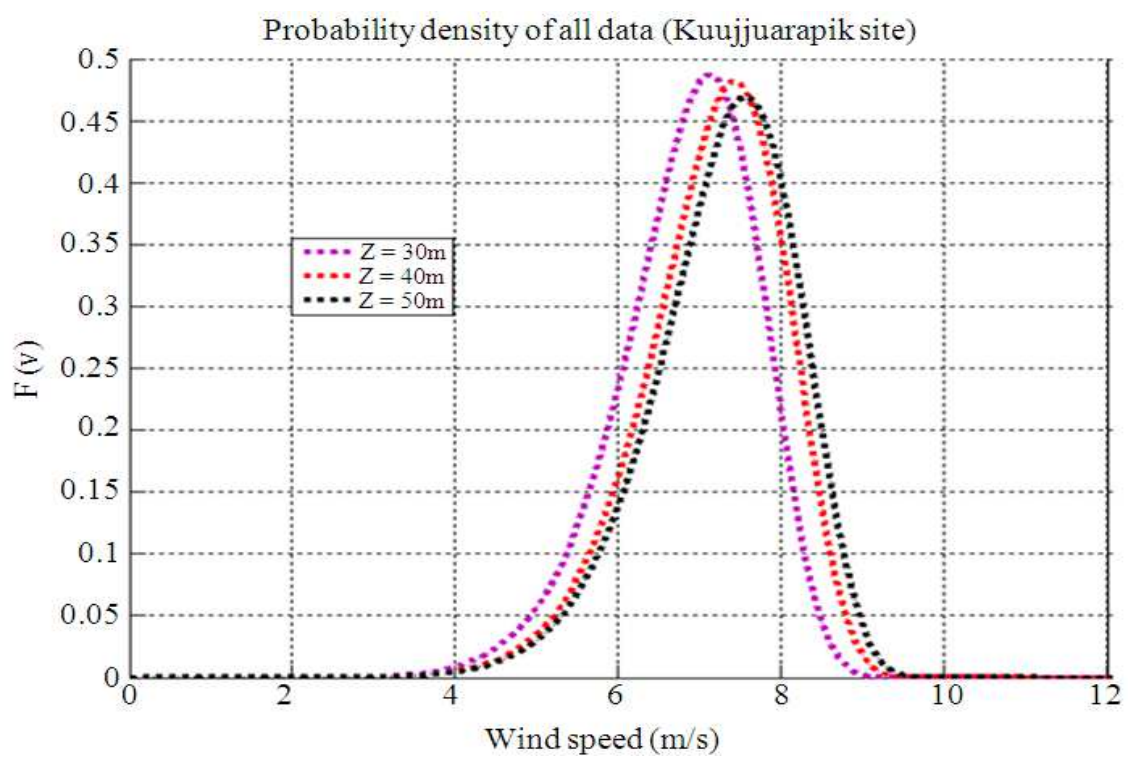

Fig. 12. Weibull distribution (Kuujjuarapik site)

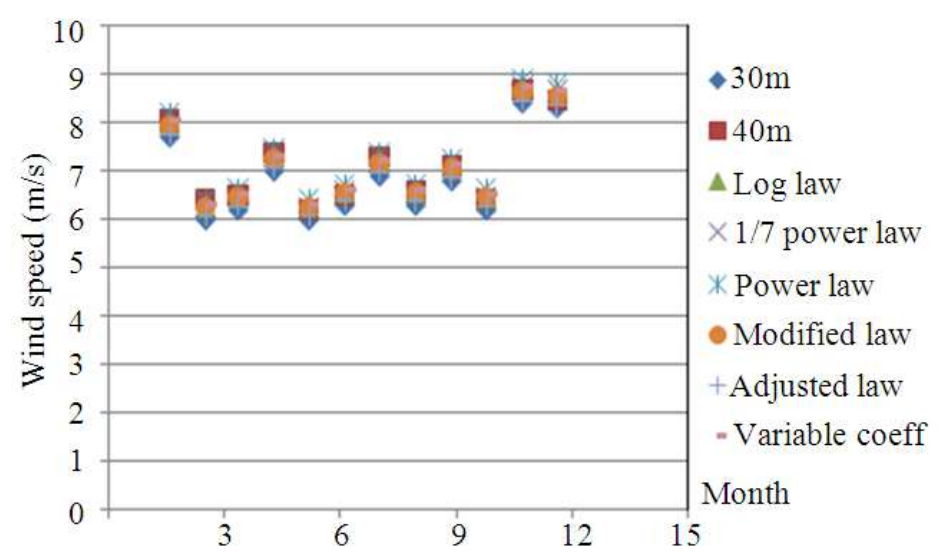

Fig. 13. Real and extrapolated data at $z=40 \mathrm{~m}$

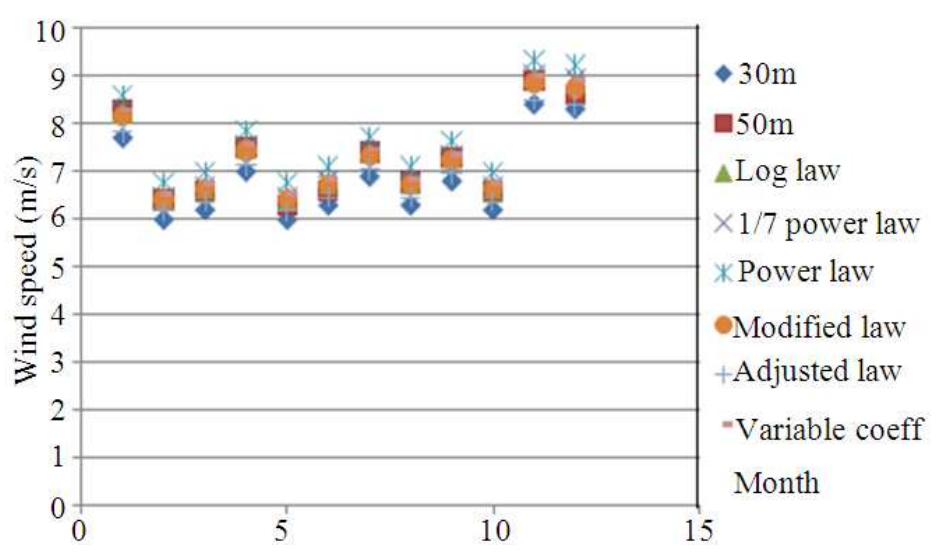

Fig. 14. Real and extrapolated data at $z=50 \mathrm{~m}$ 
Dalila Khalfa et al. / American Journal of Applied Sciences 11 (4): 570-583, 2014

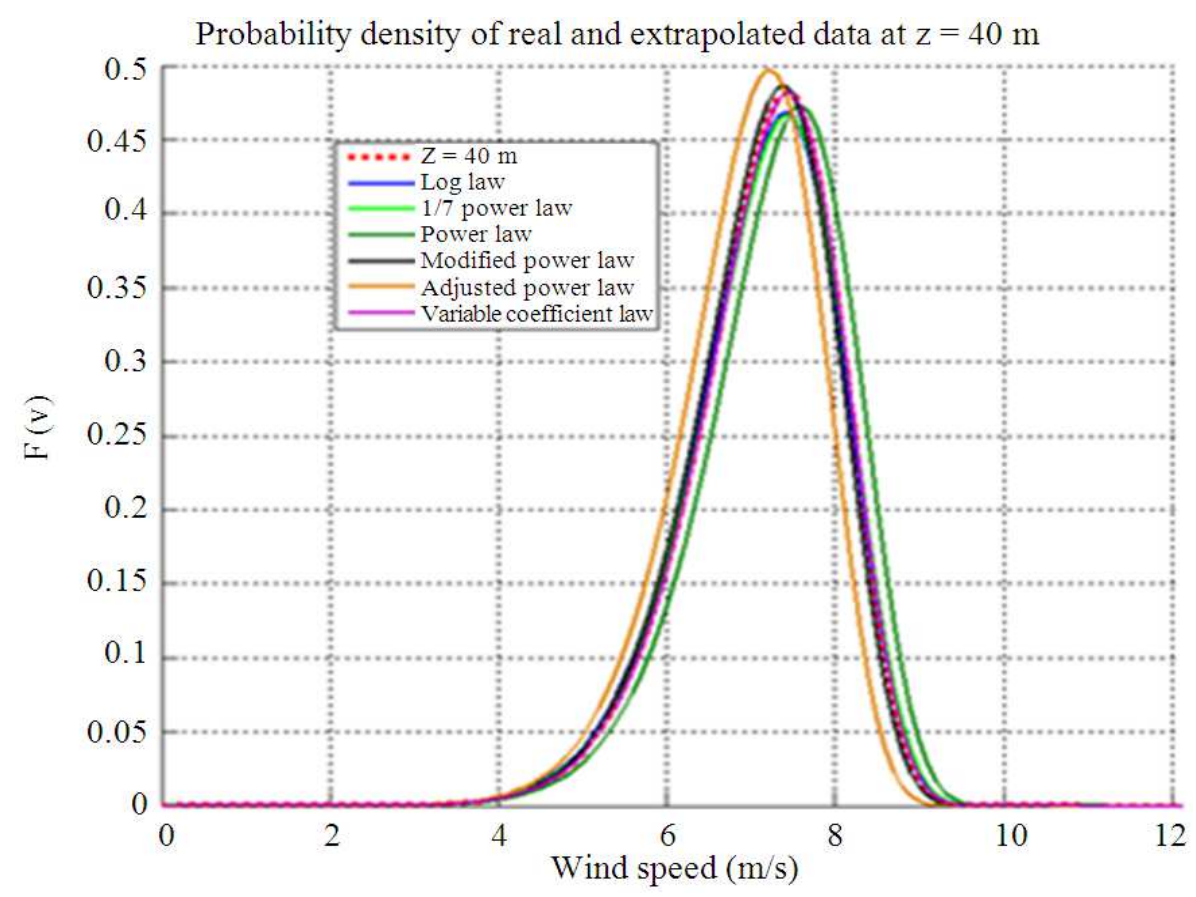

Fig. 15. Weibull distribution Real and extrapolated data $z=40 \mathrm{~m}$ (monthly measurement)

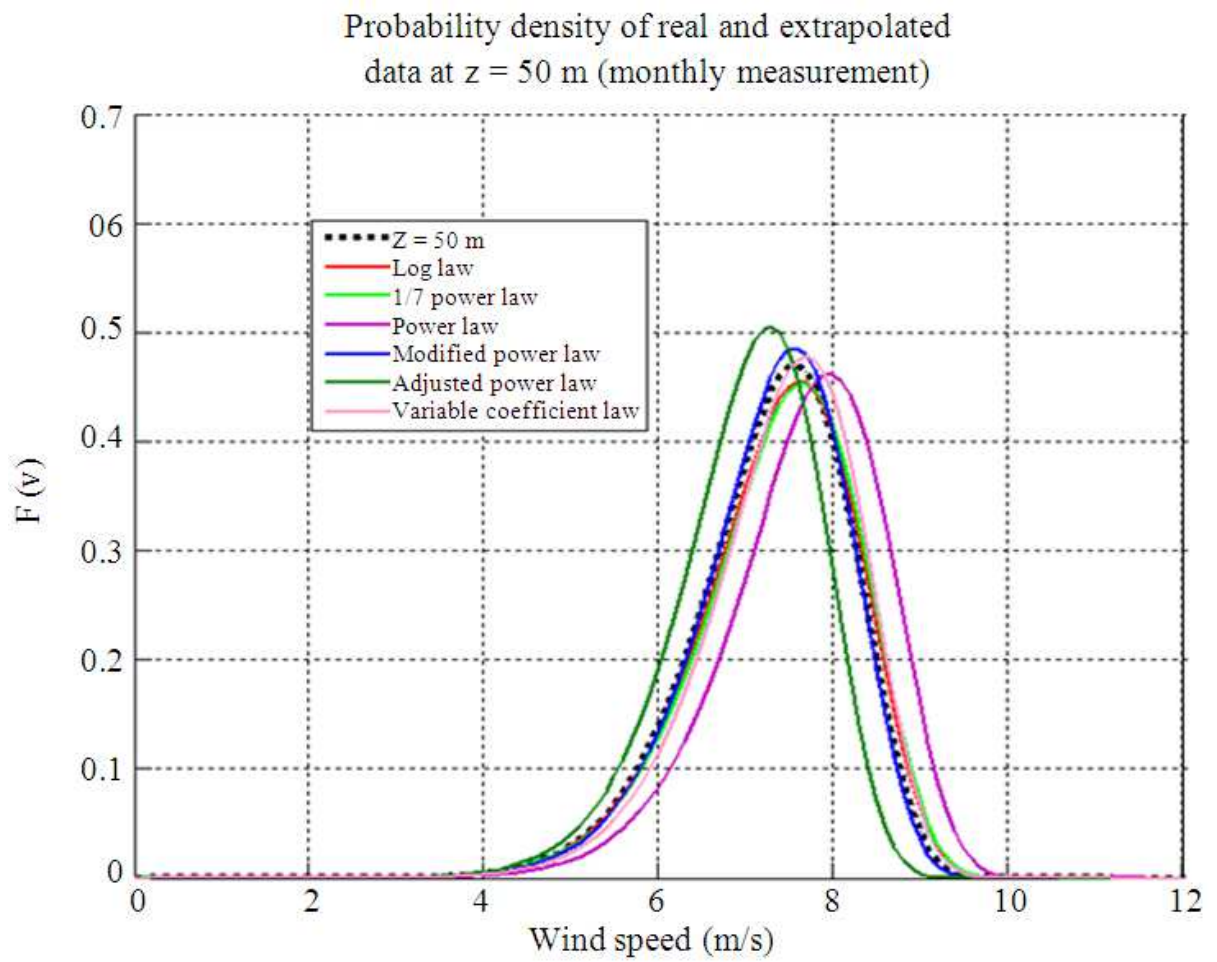

Fig. 16. Weibull distribution Real and extrapolated data $\mathrm{z}=50 \mathrm{~m}$ (monthly measurement) 
Dalila Khalfa et al. / American Journal of Applied Sciences 11 (4): 570-583, 2014

Table 4. Results and comparison between real data and data obtained by extrapolation (of $\mathrm{z}_{1}=17 \mathrm{~m}$ to $\mathrm{z}_{2}=29 \mathrm{~m}$ )

\begin{tabular}{|c|c|c|c|c|c|c|c|c|}
\hline \multirow{2}{*}{$\begin{array}{l}\text { Daily measures and } \\
\text { extrapolation law }\end{array}$} & \multicolumn{2}{|c|}{ Mean speed and variance } & \multicolumn{2}{|c|}{ Weibull parameters } & \multicolumn{4}{|c|}{ Difference between real and extrapolated data } \\
\hline & $\overline{\mathrm{v}}\left(\mathrm{m} \mathrm{sec}^{-1}\right)$ & $\delta$ & $\mathrm{k}$ & $\mathrm{c}\left(\mathrm{m} \mathrm{sec}{ }^{-1}\right)$ & $\mathrm{E}\left(\mathrm{m} \mathrm{sec}^{-1}\right)$ & $\Delta \mathrm{v}\left(\mathrm{m} \mathrm{sec}^{-1}\right)$ & $\Delta \mathrm{k}$ & $\Delta \mathrm{c}\left(\mathrm{m} \mathrm{sec}^{-1}\right)$ \\
\hline $17 \mathrm{~m}$ (Real data) & 6.0658 & 0.6627 & 11.0724 & 6.3495 & 2.6000 & - & - & - \\
\hline $29 \mathrm{~m}$ (Real data) & 6.6468 & 0.6976 & 11.5665 & 6.9458 & 2.8800 & - & - & - \\
\hline Log Power law & 6.9298 & 0.7571 & 11.0724 & 7.2539 & 2.8704 & -0.2830 & -0.4941 & -0.3081 \\
\hline 1/7 Power law & 6.5467 & 0.7153 & 11.0723 & 6.8529 & 2.8061 & 0.1001 & -0.4942 & 0.0929 \\
\hline n Power law & 6.8258 & 0.7094 & 11.6905 & 7.1300 & 2.7822 & -0.1790 & 0.1240 & -0.1842 \\
\hline Modified Power & 6.9228 & 0.7195 & 11.6905 & 7.2313 & 2.8218 & -0.2760 & 0.1240 & -0.2855 \\
\hline Adjusted Power law & 6.6575 & 0.6919 & 11.6907 & 6.9542 & 2.7136 & -0.0107 & 0.1242 & -0.0084 \\
\hline Var coeff Power law & 6.8258 & 0.7094 & 11.6905 & 7.1300 & 2.7822 & -0.1790 & 0.1240 & -0.1842 \\
\hline
\end{tabular}

Table 5. Results and comparison between real data and data obtained by extrapolation (of $\mathrm{z}_{1}=17 \mathrm{~m}$ to $\mathrm{z}_{2}=39 \mathrm{~m}$ )

\begin{tabular}{|c|c|c|c|c|c|c|c|c|}
\hline \multirow{2}{*}{$\begin{array}{l}\text { Daily measures } \\
\text { and extrapolation } \\
\text { Law }\end{array}$} & \multicolumn{2}{|c|}{ Mean speed and variance } & \multicolumn{2}{|c|}{ Weibull parameters } & \multicolumn{4}{|c|}{ Difference between real and extrapolated data } \\
\hline & $\overline{\mathrm{V}}\left(\mathrm{m} \mathrm{sec}^{-1}\right)$ & $\delta$ & $\mathrm{k}$ & $\mathrm{c}\left(\mathrm{m} \mathrm{sec}^{-1}\right)$ & $\mathrm{E}\left(\mathrm{m} \mathrm{sec}{ }^{-1}\right)$ & $\Delta \mathrm{v}\left(\mathrm{msec}^{-1}\right)$ & $\Delta \mathrm{k}$ & $\Delta \mathrm{c}\left(\mathrm{m} \mathrm{sec}^{-1}\right)$ \\
\hline $17 \mathrm{~m}$ (Real data) & 6.0658 & 0.6627 & 11.0724 & 6.3495 & 2.6000 & - & - & - \\
\hline 39 m (Real data) & 7.0506 & 0.7775 & 10.9616 & 7.3833 & 3.3300 & - & - & - \\
\hline Log Power law & 7.4091 & 0.8095 & 11.0724 & 7.7556 & 3.1758 & -0.3585 & -0.1108 & -0.3723 \\
\hline 1/7 Power law & 6.8298 & 0.7462 & 11.0724 & 7.1491 & 2.9274 & 0.5793 & -0.1108 & 0.2342 \\
\hline n Power law & 7.3009 & 0.7371 & 12.0640 & 7.6171 & 2.8855 & 0.2503 & -1.1024 & -0.2338 \\
\hline Modified Power & 7.3950 & 0.7466 & 12.0634 & 7.7153 & 2.9278 & 0.3444 & -1.1018 & -0.3320 \\
\hline Adjusted Power law & 6.9590 & 0.7026 & 12.0630 & 7.2605 & 2.7553 & 0.0916 & -1.1014 & 0.1228 \\
\hline Var coeff Power law & 7.2879 & 0.7358 & 12.0632 & 7.6036 & 2.8855 & 0.2373 & -1.1016 & -0.2203 \\
\hline
\end{tabular}

Table 6. Results and comparison between real data and data obtained by extrapolation (of $\mathrm{z}_{1}=17 \mathrm{~m}$ to $\mathrm{z}_{2}=40 \mathrm{~m}$ )

\begin{tabular}{|c|c|c|c|c|c|c|c|c|}
\hline \multirow{2}{*}{$\begin{array}{l}\text { Daily measures } \\
\text { and extrapolation } \\
\text { law }\end{array}$} & \multicolumn{2}{|c|}{ Mean speed and variance } & \multicolumn{2}{|c|}{ Weibull parameters } & \multicolumn{4}{|c|}{ Difference between real and extrapolated data } \\
\hline & $\overline{\mathrm{v}}\left(\mathrm{m} \mathrm{sec}{ }^{-1}\right)$ & $\delta$ & $\mathrm{k}$ & $\mathrm{c}\left(\mathrm{m} \mathrm{sec}^{-1}\right)$ & $\mathrm{E}\left(\mathrm{m} \mathrm{sec}{ }^{-1}\right)$ & $\Delta \mathrm{v}\left(\mathrm{msec}^{-1}\right)$ & $\Delta \mathrm{k}$ & $\Delta \mathrm{c}\left(\mathrm{m} \mathrm{sec}^{-1}\right)$ \\
\hline 17 m (Real data) & 6.0658 & 0.6627 & 11.0724 & 6.3495 & 2.6000 & - & - & - \\
\hline 40 m (Real data) & 7.0603 & 0.7439 & 11.5169 & 7.3791 & 3.1500 & - & - & - \\
\hline Log Power law & 7.4501 & 0.8140 & 11.0726 & 7.7984 & 3.1433 & -0.3898 & 0.4443 & -0.4193 \\
\hline 1/7 power law & 6.8545 & 0.7489 & 11.0720 & 7.1750 & 2.9381 & 0.2085 & 0.4449 & 0.2041 \\
\hline n power law & 7.3288 & 0.7380 & 12.0961 & 7.6455 & 2.8444 & -0.2685 & -0.5792 & -0.2664 \\
\hline Modified power law & 7.4351 & 0.7488 & 12.0962 & 7.7565 & 2.9364 & -0.3748 & -0.5793 & -0.3774 \\
\hline Adjusted power law & 6.9839 & 0.7034 & 12.0961 & 7.2857 & 2.7582 & 0.0764 & -0.5792 & 0.0934 \\
\hline Var coeff power law & 7.3288 & 0.7381 & 12.0961 & 7.6455 & 2.8944 & -0.2685 & -0.5792 & -0.2664 \\
\hline
\end{tabular}

Table 7. Results and comparison between real data and data obtained by extrapolation( of $\mathrm{z}_{1}=30 \mathrm{~m}$ to $\mathrm{z}_{2}=40 \mathrm{~m}$ )

\begin{tabular}{|c|c|c|c|c|c|c|c|c|}
\hline \multirow{2}{*}{$\begin{array}{l}\text { monthly measures } \\
\text { and extrapolation } \\
\text { Law }\end{array}$} & \multicolumn{2}{|c|}{ Mean speed and variance } & \multicolumn{2}{|c|}{ Weibull parameters } & \multicolumn{4}{|c|}{ Difference between real and extrapolated data } \\
\hline & $\overline{\mathrm{v}}\left(\mathrm{m} \mathrm{sec}^{-1}\right)$ & $\delta$ & $\mathrm{k}$ & $\mathrm{c}\left(\mathrm{m} \mathrm{sec}^{-1}\right)$ & $\mathrm{E}\left(\mathrm{m} \mathrm{sec}^{-1}\right)$ & $\Delta \mathrm{v}\left(\mathrm{m} \mathrm{sec}^{-1}\right)$ & $\Delta \mathrm{k}$ & $\Delta \mathrm{c}\left(\mathrm{m} \mathrm{sec}{ }^{-1}\right)$ \\
\hline $30 \mathrm{~m}$ & 6.8417 & 0.8607 & 9.5001 & 7.2074 & 2.4000 & - & - & - \\
\hline $40 \mathrm{~m}$ & 7.1417 & 0.8733 & 9.7977 & 7.5134 & 2.5000 & - & - & - \\
\hline Log power law & 7.1180 & 0.8955 & 9.5001 & 7.4985 & 2.4970 & 0.0237 & 0.2976 & 0.0149 \\
\hline 1/7 Power law & 7.1287 & 0.8968 & 9.5004 & 7.5225 & 2.4907 & 0.0130 & 0.2973 & -0.0091 \\
\hline n Power law & 7.2916 & 0.8907 & 9.8093 & 7.6708 & 2.4834 & -0.1499 & -0.0116 & -0.1574 \\
\hline Modified power law & 7.0904 & 0.8661 & 9.8096 & 7.4591 & 2.4184 & 0.0513 & -0.0119 & 0.0543 \\
\hline Adjusted power law & 6.9346 & 0.8471 & 9.8093 & 7.2952 & 2.3618 & 0.2071 & -0.0116 & 0.2182 \\
\hline Var coeff power law & 7.1536 & 0.8738 & 9.8094 & 7.5256 & 2.4341 & -0.0119 & -0.0117 & -0.0122 \\
\hline
\end{tabular}


Dalila Khalfa et al. / American Journal of Applied Sciences 11 (4): 570-583, 2014

Table 8. Results and comparison between real data and data obtained by extrapolation (of $\mathrm{z}_{1}=30 \mathrm{~m}$ to $\mathrm{z}_{2}=50 \mathrm{~m}$ )

\begin{tabular}{|c|c|c|c|c|c|c|c|c|}
\hline \multirow{2}{*}{$\begin{array}{l}\text { Monthly measures } \\
\text { and extrapolation } \\
\text { Law }\end{array}$} & \multicolumn{2}{|c|}{ Mean speed and variance } & \multicolumn{2}{|c|}{ Weibull parameters } & \multicolumn{4}{|c|}{ Difference between real and extrapolated data } \\
\hline & $\overline{\mathrm{v}}\left(\mathrm{m} \mathrm{sec}^{-1}\right)$ & $\delta$ & $\mathrm{k}$ & $\mathrm{c}\left(\mathrm{m} \mathrm{sec}^{-1}\right)$ & $\mathrm{E}\left(\mathrm{m} \mathrm{sec}^{-1}\right)$ & $\Delta \mathrm{v}\left(\mathrm{m} \mathrm{sec}{ }^{-1}\right)$ & $\Delta \mathrm{k}$ & $\Delta \mathrm{c}\left(\mathrm{m} \mathrm{sec}^{-1}\right)$ \\
\hline $30 \mathrm{~m}$ & 6.8417 & 0.8607 & 9.50010 & 7.2074 & 2.4000 & - & - & - \\
\hline $50 \mathrm{~m}$ & 7.2750 & 0.8956 & 9.72680 & 7.6561 & 2.6000 & - & - & - \\
\hline Log power law & 7.3323 & 0.9224 & 9.50010 & 7.7243 & 2.5721 & -0.0573 & 0.2267 & -0.0682 \\
\hline 1/7 Power law & 7.3596 & 0.9259 & 9.50020 & 7.7531 & 2.5817 & -0.0846 & 0.2266 & -0.0970 \\
\hline n Power law & 7.6610 & 0.9141 & 10.0625 & 8.0506 & 2.5485 & -0.3860 & -0.3357 & -0.3945 \\
\hline Modified power law & 7.2819 & 0.8689 & 10.0623 & 7.6523 & 2.4224 & -0.0069 & -0.3355 & 0.0038 \\
\hline Adjusted power law & 7.0002 & 0.8352 & 10.0624 & 7.3563 & 2.3287 & 0.2748 & -0.3356 & 0.2998 \\
\hline Var coeff power law & 7.4054 & 0.8836 & 10.0625 & 7.7820 & 2.4634 & -0.1304 & -0.3357 & -0.1259 \\
\hline
\end{tabular}

Table 7 and 8 collect all monthly results (real and extrapolated) analyzed and compared with the real data.

\section{DISCUSSION}

The daily data used a considerably rough Site of roughness $\mathrm{z}_{2}=0.4 \mathrm{~m}$ and measure of dispersion $\mathrm{E}$ does not exceed $3 \mathrm{~m} \mathrm{sec}^{-1}$, note that the adjusted power law is more adequate than the other laws, the calculation of the mean wind speed has gaps (between actual values and measured values) of: $\left(\Delta v=-0.0107 \mathrm{~m} \mathrm{sec}^{-1}\right)$ for extrapolation of $z_{1}=17 \mathrm{~m}$ to $z_{2}=29 \mathrm{~m}$ (Table 4), $(\Delta v=$ $0.0916 \mathrm{~m} \mathrm{sec}^{-1}$ for extrapolation of $\mathrm{z}_{1}=17 \mathrm{~m}$ to $\left.\mathrm{z}_{3}=39 \mathrm{~m}\right)$ (Table 5) and $\left(\Delta v=0.0764 \mathrm{~m} \mathrm{sec}^{-1}\right.$ for extrapolation of $\mathrm{z}_{1}=$ $17 \mathrm{~m}$ to $\mathrm{z}_{4}=40 \mathrm{~m}$ ) (Table 6).

The calculation of scale factor $\mathrm{c}$ shows a gap of: $(\Delta \mathrm{c}=$ $-0.0084 \mathrm{~m} \mathrm{sec}^{-1}$ for extrapolation of $\mathrm{z}_{1}=17 \mathrm{~m}$ to $\mathrm{z}_{2}=29$ m) (Table 4), $\left(\Delta c=0.1228 \mathrm{~m} \mathrm{sec}^{-1}\right.$ for extrapolation of $z_{1}$ $=17 \mathrm{~m}$ to $\left.\mathrm{z}_{3}=39 \mathrm{~m}\right)\left(\right.$ Table 5) and $\left(\Delta \mathrm{c}=0.0934 \mathrm{~m} \mathrm{sec}^{-1}\right.$ for extrapolation of $z_{1}=17 \mathrm{~m}$ to $z_{4}=41 \mathrm{~m}$ ) (Table 6).

The monthly data used a feeble rough site of roughness $\mathrm{z} 0=0.0242 \mathrm{~m}$ and a measure of dispersion $\mathrm{E}$ does not exceed $3 \mathrm{~m} \mathrm{sec}^{-1}$, note that the modified power law has a very small difference between real data and extrapolated data $\left(\Delta v=0.0513 \mathrm{~m} \mathrm{sec}^{-1}\right)$ and $(\Delta \mathrm{c}=0.0543 \mathrm{~m}$ $\left.\sec ^{-1}\right)$ for extrapolation of $\left(\mathrm{z}_{1}=30 \mathrm{~m}\right.$ to $\left.\mathrm{z}_{3}=40 \mathrm{~m}\right)$ (Table 7) and $\left(\Delta v=-0.0069 \mathrm{~m} \mathrm{sec}^{-1}\right)$ and $\left(\Delta c=0.0038 \mathrm{~m} \mathrm{sec}^{-1}\right)$ for extrapolation of $\left(z_{1}=30 \mathrm{~m}\right.$ to $\left.z_{3}=50 \mathrm{~m}\right)$ (Table 8), the logarithmic law and $1 / 7$ power law have also a good adequacy with the actual data, however, the modified power law is more accurate than the two latter laws.

Extrapolation laws express the increasingaltitude gen erates increasing of wind speed and the Weibull parameters ( $\mathrm{k}$ and $\mathrm{c}$ ), for the form factor $\mathrm{k}$, experimental results note that kcan take the lower values to that established in the reference altitude Table $\mathbf{2}$ and $\mathbf{3}$, which analytically is just since this factor expresses the distribution of measured around the mean values for a given period.

The scale factor $\mathrm{c}$ increases with increasing altitude and in the other hand with the increase of wind speed, which is just analytically (c have directly related to the average speed and take the same unit).

Data analysis showed that the two laws (logarithmic law and $1 / 7$ power law) keep the same form of data distribution around the average of reference data (for daily or monthly calculations) as shown in tables and figures results established.

The measure of dispersion E does not exceed $3 \mathrm{~m} \mathrm{~s}^{-1}$ for both sites studied, generates the shape factors between 9 and 11, which expresses that all the data are close to the average value.

\section{CONCLUSION}

Under the usual conditions of meteorological measurement with a roughness in the range of $[0.03 \div$ $0.1]$ therefore a shear coefficient in the range of $[0.14 \div$ $0.2]$, Power law and the log law exhibit a good coherence and good accuracy for the extrapolation of the wind speed of a reference level to a higher level.

In this study we selected two sites outside the usual range of measurement, a site with roughness $z_{0}=0.4$ $\mathrm{m}$ (City area with tall buildings) and another site with the roughness $\mathrm{z}_{0}=0.02 \mathrm{~m}$ (Airport areas with buildings and trees).

The following conclusion can be drawn from the preceding analysis:

- For highly rough meteorological sites, adjusted law is a very efficient law for the extrapolation of the wind speed and Weibull parameters of reference altitude at higher altitudes

- The logarithmic power and the $1 / 7$ power law are very effective laws to extrapolate the energy 
parameters at higher altitudes in the rough locations (low roughness) however the modified power law provides a good level of accuracy more the two previous laws

- The increase in altitude generates the increasing of wind speed and the scale factor c (these two parameters are related one to other)

- The increase in altitude does not generate constantly increasing form factor $\mathrm{k}$ (this factor shows the distribution of data around the mean)

- The measure of dispersion E calculated using the laws extrapolation of wind speed does not exceed the extent obtained in reality

- Both extrapolation laws (the logarithmic law and the $1 / 7$ power law) keep the same form of data distribution around the mean of the reference altitude $(\mathrm{k} \approx$ constant)

- The reduction of the measure of dispersion $\mathrm{E}$ generates the high factors form $\mathrm{K}$ (this factor expresses the adjacent data around the mean).

- In the prospects studies, we propose to target research towards a law extrapolation that encompasses the full range of roughness and can be applied with high accuracy just any type of soil

\section{REFERENCES}

Elkinton, M.R., A.L. Rogers and J.G. McGowan, 2006. An investigation of wind-shear models and experimental data trends for different terrains. Wind Eng., 30 : 341-350. $10.1260 / 030952406779295417$

Hsu, S.A., E.A. Meindl and D.B. Gilhousen, 1994. Determining the power-law wind-profile exponent under near-neutral stability conditions at sea. J. Applied Meteorol., 33: 757-772. DOI: 10.1175/1520-0450(1994)0332.0.CO;2

Justus, C.G. and A. Mikhail, 1976. Height variation of wind speed and wind distributions statistics. Geophys. Res. Lett., 3261-264. DOI: 10.1029/GL003i005p00261

Justus, C.G., W.R. Hargraves and A. Yalcin, 1976. Nationwide assessment of potential output from wind-powered generators. J. Applied Meteorol., 15: 673-678. DOI:

$10.1175 / 1520-$ 0450(1976)015<0673:NAOPOF>2.0.CO;2

Justus, C.G., W.R. Hargraves, A. Mikhail and D. Graber, 1978. Methods for estimating wind speed frequency distributions. J. Applied Meteorol., 17: 350-353. DOI: $10.1175 / 1520-$ 0450(1978)017<0350:MFEWSF>2.0.CO;2
Manwell, J.F., J.G. McGowan and A.L. Rogers, 2010. Wind Energy Explained: Theory. 2nd Edn., John Wiley and Sons, ISBN-10: 0470686286, pp: 704.

Mikhail, A.S. and C.G. Justus, 1981. Comparison of height extrapolation models and sensitivity analysis. Wind Eng.

Mikhail, A.S., 1985. Height extrapolation of wind data. J. Solar Energy Eng., 107: 10-14. DOI: 10.1115/1.3267645

Motta, M., R.J. Barthelmie and P. Volund, 2005. The influence of non-logarithmic wind speed profiles on potential power output at Danish offshore sites. Wind Energy, 8: 219-236. DOI: 10.1002/we.146

Nfaoui, H., J. Buret and A.A.M. Sayigh, 1998. Wind characteristics and wind energy potential in Morocco. Solar Energy, 63: 51-60. DOI: 10.1016/S0038-092X(98)00040-1

Perez, I.A., M.A. Garcia, M.L. Sanchez and B.D. Torre, 2005. Analysis and parameterisation of wind profiles in the low atmosphere. Solar Energy, 78: 809-821. DOI: 10.1016/j.solener.2004.08.024

Peterson, E.W. and J.P. Jr. Hennessey, 1978. On the use of power laws for estimates of wind power potential. J. Applied Meteorol., 17: 390-394. DOI: 10.1175/15200450(1978)017<0390:OTUOPL > 2.0.CO;2

Poje, S. and B. Cividini, 1988. Assessment of wind energy potential in Gaza strip. Solar Energy, 41: 543-554.

Ray, M.L., A.L. Rogers and J.G. McGowan, 2006. Analysis of wind shear models and trends in different terrain. University of Massachusetts.

Rocha, P.A.C., R.C. De Sousa and C.F. De An-Drade, 2012. Comparison of seven numerical methods for determining Weibull parameters for wind energy generation in the northeast region of Brazil. Applied Energy, 89: 395-400. DOI: 10.1016/j.apenergy.2011.08.003

Rogers, A.L., J. Manwell and A. Ellis, 2005. Wind shear over forested areas. University of Massachusetts.

Schwartz, M and D. Elliott, 2006. Wind shear characteristics at central plains tall towers. Proceedings of the American Wind Energy Association Wind Power, Jun. 2-7, Pittsburgh, PA, USA.

Tennekes, H., 1973. The logarithmic wind profile. J. Atmos. Sci., 30: 234-238. DOI: 10.1175/15200469(1973)030<0234:TLWP > 2.0.CO;2

Troen, I. and E.L. Petersen, 1998. European Wind Atlas. 1st Edn., Risoe National Laboratory, ISBN-10: 8755014828. Danemark, pp: 656. 